\title{
Equilibrium
}

Quarterly Journal of Economics and Economic Policy

2015 VOLUME 10 ISSUE 3, September

p-ISSN 1689-765X, e-ISSN 2353-3293

www.economic-policy.pl

Sobański, K. (2015). Valuation Effect as a Determinant of the International Investment Position in Central and Eastern European Economies. Equilibrium. Quarterly Journal of Economics and Economic Policy, 10(3), pp. 151-164, DOI: http://dx.doi.org/10.12775/ EQUIL.2015.030

Konrad Sobański* Poznan University of Economics, Poland

\section{Valuation Effect as a Determinant of the International Investment Position in Central and Eastern European Economies}

JEL Classification: $F 36$; $F 41 ; F 62 ; G 15$

Key words: international finance; valuation effect; international investment position; Central and Eastern European economies

\begin{abstract}
The aim of this paper is to evaluate the significance of the valuation effect in determining the dynamics of the net international investment position of CEE economies. For this purpose an analysis of BoP and IIP time series for the four largest CEE economies (Poland, the Czech Republic, Hungary and Romania) for the years 2005-2013 was carried out. The exercise revealed that the valuation effect (VE) is, in the short run, the key determinant of net IIP changes (for most observed years). Nevertheless, in the long-run its influence decreases as valuation gains and losses tend to cancel each other out. As the VE is relatively volatile, it is important to analyse its dynamics over the mid and long-term when evaluating the IIP. The significance of the VE for determining net IIP dynamics turned out to be non-investment-type specific because valuations of both the short-term and longterm investments contributed in a large part to the change in the net IIP. Similarities in the dynamics of the VE in CEE countries prove that the VE depends to a large extent on the general price fluctuations in financial markets that nowadays exhibit strong correlations across countries.
\end{abstract}

(C) Copyright Institute of Economic Research \& Polish Economic Society Branch in Toruń Date of submission: March 14, 2015; date of acceptance: June 1, 2015

* Contact: konrad.sobanski@ue.poznan.pl, Poznan University of Economics, Faculty of International Business and Economics, International Finance Department, al. Niepodległości 10, 61-875 Poznań, Poland 


\section{Introduction}

Economic transactions between residents and nonresidents influence the level of foreign assets and liabilities compounding the international investment position (IIP) of a national economy. The IIP, being an international balance sheet of the economy, is one of the closely analysed variables when evaluating an economy's external position. The net IIP, measured as a difference between the levels of foreign assets and liabilities, indicates whether the economy is a net debtor or creditor to the rest of the world, which in turn defines risks to which the economy is exposed in an international context. However, international transactions are not the only determinant of net IIP fluctuations. The other factor underlying the changes in the net IIP are valuation adjustments to existing stocks of assets and liabilities.

Empirical research indicates a significant role for the valuation adjustment in determining the IIP in developed countries and in some developing countries. Lane and Milesi-Ferretti (2001) estimate foreign assets and liabilities for 67 countries (excluding Central and Eastern European transition economies) for the period 1970-1998 based on balance of payments data and explore the sensitivity of the estimates to the valuation adjustment. They indicate that the valuation effects are quantitatively important for a number of countries in the sample. Higgins et al. (2007) prove a large role for the valuation effect in determining the net IIP of the United States during the period 2001-2005. Gourinchas (2008) indicates that short-term fluctuations in a country's external asset position appear to be increasingly driven by the valuation component. He measures the cumulative valuation effect (since 1950) in a sample of industrialised countries and concludes that it is significant and has been growing in recent years: reaching $50 \%$ of GDP in the UK in 2000, 20\% of GDP in the US and Canada in 2004 and slightly less in Australia. Macias and Nash (2007) point out that the valuation adjustment explains 55\% of the change in the Spanish net IIP between 1993 and 2004. Devereux and Sutherland (2010) measure the importance of the valuation term in a sample of 23 OECD countries during the period 1980-2006. As the ratio for the variance of the valuation term to the variance of the change in net IIP is well above 50\% for most countries, they conclude that the evolution of the net IIP is dominated by valuation gains and losses resulting from changes in asset prices and exchange rates. Gourinchas and Rey (2013) measure valuation effects for 10 countries in the 1970s, 1980s, 1990s and 2000s. Their research indicates that the importance of the valuation effect has been increasing over time and the average magnitude of the current account transactions tend to be dominated by the average magnitude of valuation effects for determining the IIP adjust- 
ment in most of the countries analysed (the US, the UK, Ireland, Brazil, Russia, India, Switzerland).

During the decade after the accession to the European Union, the financial integration of Central and Eastern European economies (CEE) with the rest of the world advanced, which significantly influenced their IIP. Throughout this period, the changes in the valuation of foreign assets and liabilities were important in terms of determining the net IIP of CEE countries amid price fluctuations in international financial markets. The aim of this paper is to evaluate the significance of the valuation effect for determining the dynamics of the net IIP in CEE economies. Within the empirical research conducted the following hypotheses were verified:

- the valuation adjustment of foreign assets and liabilities as the key determinant of the net IIP dynamics in CEE economies,

- the significance of the valuation effect in determining the dynamics of net IIP in CEE economies as investment-type specific because investments of a short-term nature tend to be associated with a larger valuation effect.

In order to verify the hypotheses, a statistical decomposition of a time series for balance of payments and IIP data was conducted. The research method applied is based on the commonly used accounting framework for balance of payments and IIP. The time span of the analysis covers the years 2005-2013. The sample consists of the four largest CEE economies based on GDP ${ }^{1}$ ranking; i.e. Poland, the Czech Republic, Hungary and Romania ${ }^{2}$.

The structure of the paper is as follows. The first section depicts methodological aspects related to measuring fluctuations in the net IIP. In the next section fluctuations in the external investment position of CEE economies are presented and decomposed into contributing factors. The third section describes the significance of the valuation adjustment for major types of international investments. The conclusions from the analysis are presented in the final section.

\section{Methodology of the Research}

A change in the net IIP position is the outcome of changes in stocks of foreign assets and foreign liabilities, which are in turn determined by foreign transaction flows and valuation adjustments. There are two approaches to

\footnotetext{
${ }^{1}$ GDP at market prices in 2013 amounted to 389.7 billion EUR in Poland; 149.5 billion EUR in the Czech Republic; 142.2 billion EUR in Hungary, and 98.0 billion EUR in Romania (Eurostat data).

${ }^{2}$ Research project supported with funds from the National Science Centre.
} 


\section{Konrad Sobański}

measuring the determinants of net IIP changes. The first approach is to look at financial flows between residents and nonresidents, which include official reserve asset transactions. The second approach emphasizes flows resulting from current transactions as the reason for net IIP changes. Through balance of payments accounting identity, financial flows (including reserve asset transactions) are a counterpart to current transactions (including current and capital account transactions as well as errors and omissions). As a consequence a deficit / surplus stemming from current transactions in the balance of payments is associated with a surplus / deficit in financial flows, which in turn leads to a decrease / an increase in the net IIP of an econo$\mathrm{my}^{3}$.

$$
\begin{gathered}
\triangle N I I P=C A B+K A B+E O+V E \\
C A B+K A B+E O=-(F A B+R E S)
\end{gathered}
$$

where:

$\triangle$ NIIP - change in the net international investment position,

$\mathrm{CAB}$ - current account balance,

KAB - capital account balance,

EO - errors and omissions,

FAB - financial account balance,

RES - reserve asset transactions (balance on official settlement transactions).

The valuation effect (adjustment) is defined in the paper as a change in the net IIP which does not stem from foreign transaction flows. As a consequence the valuation adjustment is derived as the difference between the actual change in the net IIP and the balance on financial flows for a given period:

$$
V E=\Delta N I I P+(F A B+R E S)
$$

where:

VE - valuation effect, with the rest of the notation as presented above.

\footnotetext{
${ }^{3}$ Changes in the net IIP can also be analysed on a relative basis (by looking at changes in the ratio of net IIP to GDP). The concept of the dynamics of external positions measured on a relative basis is presented in Lane and Milesi-Ferretti (2007a, pp. 73-74; 2007b, pp. 531-533, 565-567).
} 


\section{Fluctuations in the Net External Investment \\ Position of CEE economies - an Analysis of the Underlying Factors}

The abovementioned concept is exemplified below using the IIP data of CEE economies in the years 2005-2013. All four analysed CEE economies were net international debtors throughout the period as foreign liabilities surpassed foreign assets. What is more, in the analysed period the economies experienced a drop in the net IIP as the increase in foreign liabilities outpaced the growth in foreign assets ${ }^{4}$. In absolute terms, the mismatch between the growth in assets and liabilities was most noticeable in Poland (243.8 billion USD) and least significant in Hungary (17.5 billion USD) $)^{5}$. Among current transactions, the major contributor to the decrease in the net IIP in all CEE countries was the current account deficit (ranging from 29.2 billion USD in Hungary to 174.2 billion USD in Poland). At the same time, the capital account closed with a positive balance in all countries (mainly as a result of capital transfers from the European Union), positively affecting the net IIP level. Statistical discrepancies closed with a negative balance in all countries.

The combined current and capital account deficit (including errors and omissions) was reflected through an inflow of capital, leading to a positive balance in the financial account (adjusted for official settlement transactions). In the whole period analysed, the financial flow ranged from 24.8 billion USD in Hungary to 170.3 billion USD in Poland. Whereas in the early years of the period the financial flow was a negative contributor to the net IIP adjustment in all CEE economies, later, the situation started to change. In 2009 the contribution of the financial flow began to diminish or even reverse to the positive side in some countries as a result of prevailing current account reversals (in Hungary, even turning trade deficits into trade surpluses).

The other factor influencing the net IIP was the valuation effect. The direction of its influence was different across the economies analysed. In Hungary, valuation adjustments led to an improvement in the net IIP for the years 2005-2013 (by 7.3 billion USD); whereas in Poland, the Czech Republic and Romania, to its deterioration (by 73.6, 20.8 and 7.9 billion USD respectively).

\footnotetext{
${ }^{4}$ For a detailed analysis of the IIP dynamics in CEE economies during the period 19982007 see Sobanski (2010, pp.150-170).

${ }^{5}$ In relative terms, the decrease in the net IIP for the analysed period amounted to $6.6 \%$ of GDP in Poland, and 1.5\% of GDP in Hungary.
} 
Table 1. Factors underlying changes in the net IIP of CEE economies for the years 2005-2013 (billion USD)

\begin{tabular}{|c|c|c|c|c|c|c|c|c|c|c|}
\hline & 2005 & 2006 & 2007 & 2008 & 2009 & 2010 & 2011 & 2012 & 2013 & $\begin{array}{l}2005- \\
2013\end{array}$ \\
\hline \multicolumn{11}{|c|}{ Poland } \\
\hline 1. Change in net IIP & 0.7 & -38.4 & -75.0 & -1.3 & -34.9 & -35.2 & 26.3 & -56.3 & -29.8 & -243.8 \\
\hline 2. Current account & -7.2 & -13.2 & -26.5 & -35.0 & -17.2 & -24.0 & -25.8 & -18.3 & -7.1 & -174.2 \\
\hline 3. Capital account & 1.0 & 2.1 & 4.8 & 6.1 & 7.0 & 8.6 & 10.0 & 11.0 & 12.0 & 62.6 \\
\hline $\begin{array}{l}\text { 4. Errors and omis- } \\
\text { sions }\end{array}$ & -0.8 & 0.3 & -3.3 & -12.2 & -10.0 & -10.5 & -9.9 & -4.1 & -8.2 & -58.7 \\
\hline 5. Valuation effect & 7.7 & -27.7 & -49.9 & 39.7 & -14.7 & -9.3 & 52.0 & -44.9 & -26.5 & -73.6 \\
\hline 6. Total $(2 .+3 .+4 .+5)$. & 0.7 & -38.4 & -75.0 & -1.3 & -34.9 & -35.2 & 26.3 & -56.3 & -29.8 & -243.8 \\
\hline $\begin{array}{l}\text { 7. - (Financial account } \\
+ \text { reserve asset trans- } \\
\text { actions) }(2 .+3 .+4 .)\end{array}$ & -7.0 & -10.8 & -25.0 & -41.0 & -20.2 & -25.9 & -25.7 & -11.4 & -3.3 & -170.3 \\
\hline \multicolumn{11}{|c|}{ Czech Republic } \\
\hline 1. Change in net IIP & 2.8 & -17.9 & -26.5 & -1.4 & -14.2 & -3.5 & 6.5 & -7.3 & 9.4 & -52.2 \\
\hline 2. Current account & -1.2 & -3.1 & -7.9 & -4.8 & -4.8 & -7.6 & -6.1 & -2.6 & -2.9 & -41.0 \\
\hline 3. Capital account & 0.2 & 0.4 & 1.1 & 1.6 & 2.7 & 1.7 & 0.8 & 2.7 & 3.8 & 15.1 \\
\hline $\begin{array}{l}\text { 4. Errors and omis- } \\
\text { sions }\end{array}$ & -1.7 & -1.8 & 1.3 & 0.2 & -2.6 & -1.1 & 0.8 & 0.3 & -0.7 & -5.5 \\
\hline 5. Valuation effect & 5.5 & -13.4 & -21.0 & 1.6 & -9.4 & 3.4 & 11.0 & -7.7 & 9.1 & -20.8 \\
\hline 6. Total $(2 .+3 .+4 .+5)$. & 2.8 & -17.9 & -26.5 & -1.4 & -14.2 & -3.5 & 6.5 & -7.3 & 9.4 & -52.2 \\
\hline $\begin{array}{l}\text { 7. - (Financial account } \\
+ \text { reserve asset trans- } \\
\text { actions) }(2 .+3 .+4 .)\end{array}$ & -2.7 & -4.4 & -5.5 & -3.0 & -4.8 & -7.0 & -4.6 & 0.4 & 0.2 & -31.3 \\
\hline \multicolumn{11}{|c|}{ Hungary } \\
\hline 1. Change in net IIP & 0.5 & -23.5 & -11.7 & -16.4 & -11.9 & 20.6 & 16.3 & 2.3 & 6.2 & -17.5 \\
\hline 2. Current account & -8.2 & -8.4 & -10.0 & -10.9 & -1.0 & 0.3 & 1.1 & 2.3 & 5.5 & -29.2 \\
\hline 3. Capital account & 0.7 & 0.7 & 1.0 & 1.7 & 2.3 & 2.4 & 3.3 & 3.3 & 4.9 & 20.2 \\
\hline $\begin{array}{l}\text { 4. Errors and omis- } \\
\text { sions }\end{array}$ & -2.6 & -2.7 & -0.3 & -3.5 & -1.2 & -1.3 & -3.5 & 0.5 & -1.0 & -15.7 \\
\hline 5. Valuation effect & 10.6 & -13.1 & -2.4 & -3.6 & -12.0 & 19.3 & 15.4 & -3.7 & -3.2 & 7.3 \\
\hline 6. Total $(2 .+3 .+4 .+5)$. & 0.5 & -23.5 & -11.7 & -16.4 & -11.9 & 20.6 & 16.3 & 2.3 & 6.2 & -17.5 \\
\hline $\begin{array}{l}\text { 7. - (Financial account } \\
+ \text { reserve asset trans- } \\
\text { actions) }(2 .+3 .+4 .)\end{array}$ & -10.1 & -10.4 & -9.3 & -12.8 & 0.1 & 1.4 & 0.9 & 6.1 & 9.4 & -24.8 \\
\hline \multicolumn{11}{|c|}{ Romania } \\
\hline 1. Change in net IIP & -4.9 & -21.2 & -31.1 & -17.3 & -10.7 & 2.2 & -5.1 & -8.9 & -2.1 & -99.1 \\
\hline 2. Current account & -8.5 & -12.8 & -23.1 & -23.7 & -7.0 & -7.3 & -8.3 & -7.5 & -1.8 & -99.9 \\
\hline 3. Capital account & 0.7 & -0.0 & 1.1 & 0.9 & 0.9 & 0.3 & 1.0 & 2.5 & 4.3 & 11.8 \\
\hline
\end{tabular}


Table 1 continued

\begin{tabular}{|c|c|c|c|c|c|c|c|c|c|c|}
\hline & 2005 & 2006 & 2007 & 2008 & 2009 & 2010 & 2011 & 2012 & 2013 & $\begin{array}{l}2005- \\
2013 \\
\end{array}$ \\
\hline \multicolumn{11}{|c|}{ Romania } \\
\hline $\begin{array}{l}\text { 4. Errors and omis- } \\
\text { sions }\end{array}$ & 0.6 & 0.5 & -1.3 & -2.1 & -1.7 & -0.1 & 0.6 & 1.1 & -0.7 & -3.1 \\
\hline 5. Valuation effect & 2.3 & -8.9 & -7.8 & 7.5 & -3.0 & 9.3 & 1.6 & -5.0 & -3.9 & -7.9 \\
\hline 6. Total $(2 .+3 .+4 .+5)$. & -4.9 & -21.2 & -31.1 & -17.3 & -10.7 & 2.2 & -5.1 & -8.9 & -2.1 & -99.1 \\
\hline $\begin{array}{l}\text { 7. -(Financial account } \\
+ \text { reserve asset trans- } \\
\text { actions) }(2 .+3 .+4 .)\end{array}$ & -7.2 & -12.3 & -23.3 & -24.9 & -7.8 & -7.1 & -6.7 & -3.9 & 1.8 & -91.2 \\
\hline
\end{tabular}

Other remarks: A negative change in the net IIP results from the relative increase of foreign liabilities as compared to assets (i.e. a larger increase in liabilities than assets or a smaller decrease in liabilities than assets). Current account, capital account, errors and omissions, financial account, and reserve asset transactions represent respective balances from the balance of payments. The valuation effect represents the change in the net IIP resulting from valuation adjustments to stocks of foreign assets and liabilities.

Source: own compilation on the basis of International Monetary Fund data (International Financial Statistics, Balance of Payments Statistics).

The significance of the valuation effect is even more apparent when one analyses the annual data. The VE was the major determinant of the IIP changes in most observed years in Poland, the Czech Republic and Hungary; and in one third of cases in Romania. The average annual contribution of the VE to net IIP fluctuations far exceeded 50\% in Poland, the Czech Republic and Hungary (amounting to 60\%, 69\% and 56\% respectively) and was close to $40 \%$ in Romania ${ }^{6}$. The significance of the valuation adjustment is also apparent when compared to the size of the respective economy. On average it amounted 3.5\% of GDP each year in Romania and more than $6 \%$ of GDP in the remaining CEE countries ${ }^{7}$.

The contribution of the VE was relatively volatile as it changed the sign from a positive to a negative one (and vice versa) several times. In the years preceding the outbreak of the world financial crisis, valuation adjustments increased the net foreign liabilities of CEE economies, which was a reflection of the rising prices of financial instruments across the globe. For instance, in 2007 the net IIP deteriorated by almost 14\% of GDP in Poland and the Czech Republic simply as a result of valuation amendments to existing stocks of foreign assets and liabilities. In the years 2010-2011 the VE positively affected the net IIP; leading to a drop in the net foreign liabilities

\footnotetext{
${ }^{6}$ The contribution is estimated as the relation of the absolute value (modulus) of the VE to the sum of the absolute values of the VE and the financial flow.

${ }^{7}$ The average is calculated based on the absolute values of the VE.
} 
of CEE economies (this was especially apparent in Hungary, where the positive contribution exceeded $11 \%$ of GDP in each year).

Figure 1. Decomposition of changes in the net IIP of CEE economies for the years 2005-2013
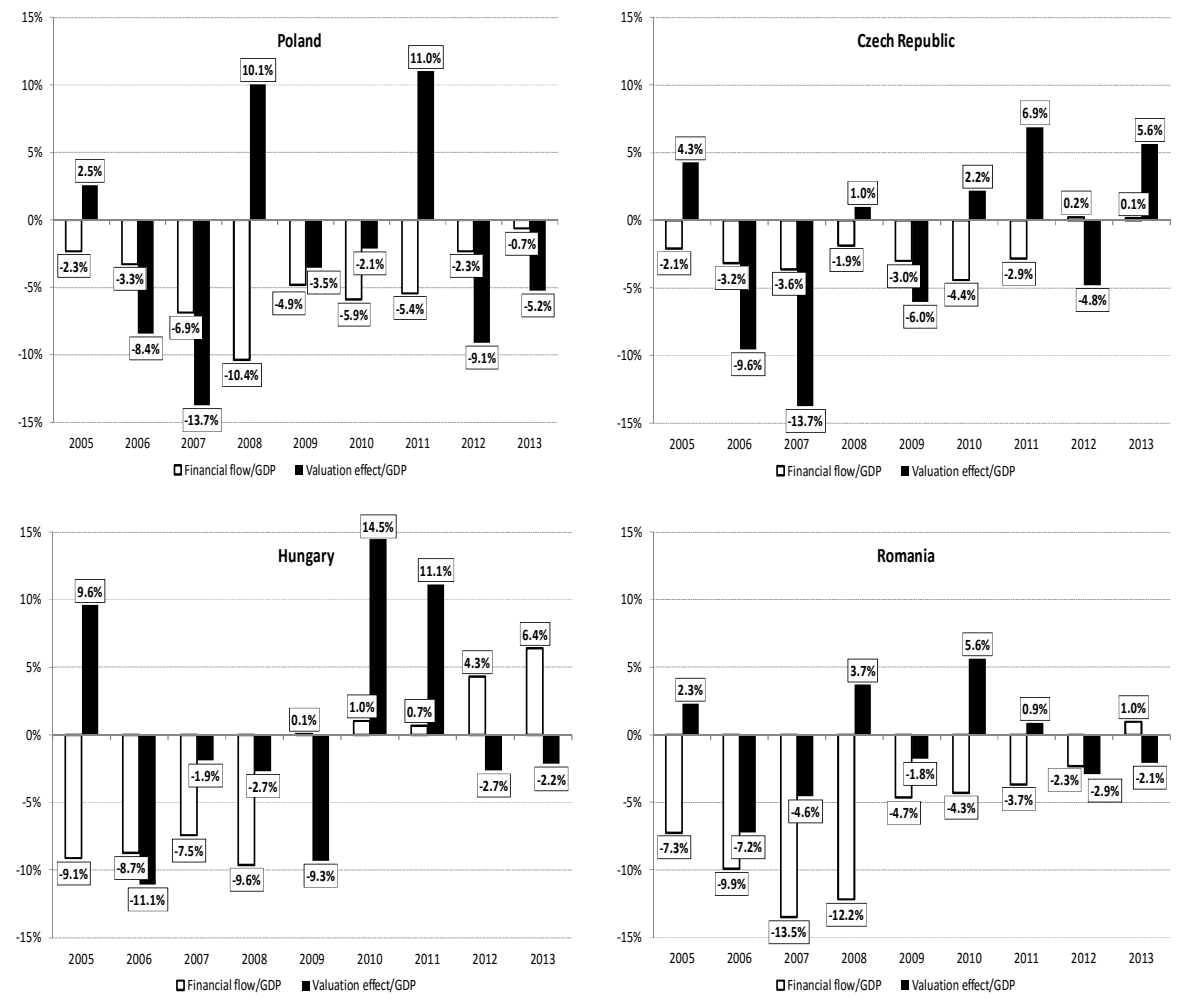

Other remarks: The financial flow represents the contribution of the financial account balance and official transactions in reserve assets to changes in the net IIP. The VE represents the change in the net IIP resulting from valuation adjustments to stocks of assets and liabilities. Both variables are presented on a relative basis, i.e. as a share of GDP.

Source: own compilation on the basis of IMF data (IFS, BoPS), OECD data, and Euromoney Institutional Investor Company data (CEIC). 


\section{The Valuation Adjustment \\ for Different Types of International Capital Flows in CEE Economies}

The VE for the net IIP can be decomposed into the valuation effect on the assets side as well as the liabilities side of the investment position. As both assets and liabilities are not uniform categories it is advisable to further analyse different categories of investments, compounding assets and liabilities separately. One can differentiate between foreign direct investments, portfolio investments, other investments and derivatives. Additionally, reserve assets play an important role on the assets side of the IIP.

In general, there is no clear indication in CEE countries that a specific type of international investment was dominant in creating exposure to the valuation effect for the net IIP. Exposure by investment type was differentiated across countries and time as well as between assets and liabilities.

In the largest CEE economy, i.e. Poland, the average annual valuation effect (2005-2013) for all types of assets did not surpass $0.7 \%$ of GDP. In the Czech Republic portfolio assets were among most affected by valuation adjustments (1.7\% GDP on average). In Hungary valuations of FDI, derivative assets and other investments fluctuated by more than $2.9 \%$ of GDP on average. However, it should be taken into account that the huge valuation adjustments to FDI stocks occurring since 2006 are in large measure due to a change in the methodology of presenting transactions of SPEs ${ }^{8}$ in this country. In Romania, valuation adjustments were much less significant than in other countries, as foreign assets were of much lower importance in the national economy (one exception being official reserve assets).

\footnotetext{
${ }^{8}$ The change in methodology followed an amendment to corporate tax law in 2002 that ended offshore status for tax purposes. From 2006, the MNB (Hungarian Central Bank) reported the balance of payments and international investment position data to international institutions in accordance with international statistical standards to allow for international and bilateral comparisons of statistics. As a result, data on flows and stocks of SPEs (enterprises set up in Hungary solely for tax optimisation purposes) are recorded on a gross basis. Thus, comparability of data for 2006-2013 with data for previous periods is limited. See (MNB, 2014a; ECB, 2007, pp. 359-360; UN Economic Commission for Europe, Eurostat and OECD, 2011, pp. 60-63).

SPEs activities are of a relatively large size in comparison to Hungarian GDP. According to the MNB the total gross loan portfolio of SPEs hovers in the range of 20-40 per cent of GDP (MNB, 2014b, p. 31). However, one should take into account that the operations of SPEs playing a passive role in the intermediation of financial resources within international capital groups can lead to misinterpretation when analysing the real economic impact on the domestic economy. SPEs' operations are mainly limited to gathering funds from foreign sources and channelling them abroad. As a consequence, gross credit and debit flows resulting from SPE operations are of a similar magnitude and net flows over an extended period are close to zero (MNB, 2014a, 2014b).
} 
Figure 2. Decomposition of the valuation effect on foreign assets of CEE economies for the years 2005-2013 (by investment type)
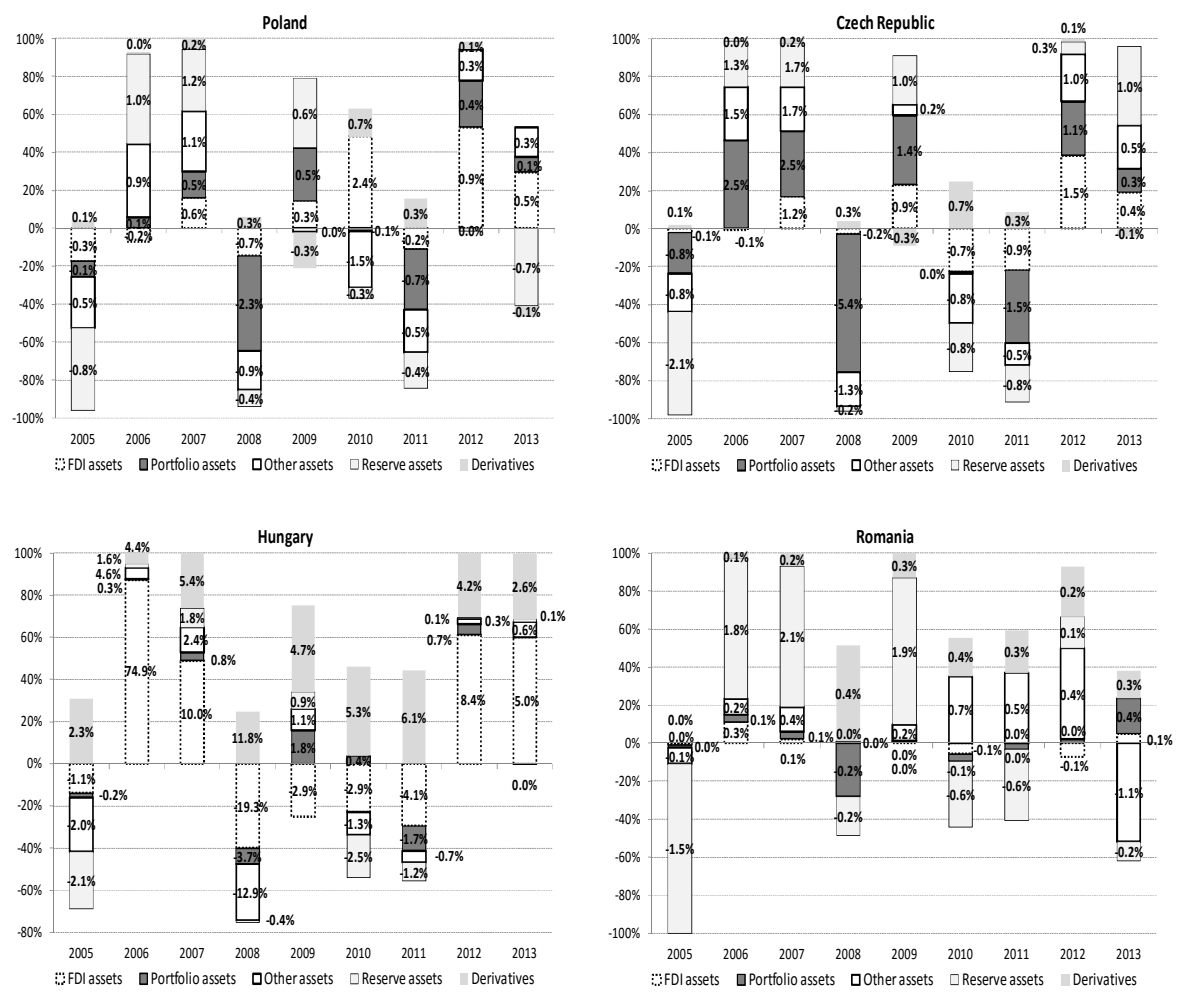

Other remarks: The height of the bar for each year is equal to $100 \%$ and is measured on the $y$-axis. The height of a section of the bar represents the share of a given type of asset in the total VE in a given year. Numbers provided within a bar or alongside represent valuation effects for the respective assets presented as a share of GDP in a given year.

Source: as in Figure 1.

CEE economies are net international debtors and their foreign liabilities exceed by far their foreign assets. For this reason the influence of the $\mathrm{VE}$ in respect of liabilities on the net IIP is usually much more significant than that of the valuation adjustment for assets. This was clearly observable in the period analysed.

In all CEE economies the changes in FDI valuations were at the forefront of liability fluctuations (with an annual average influence of $5.1 \%$ of 
GDP in Poland, 6.4\% in the Czech Republic, $17.0 \%$ in Hungary ${ }^{9}$ and $2.6 \%$ in Romania $)^{10}$. For portfolio liabilities the VE was also differentiated across countries: from $0.4 \%$ GDP in Romania to $5.6 \%$ in Hungary. The average annual adjustments to the valuation of other liabilities amounted to app. $1.7 \%$ of GDP in Poland, the Czech Republic and Romania, and around twice as much in Hungary. Liabilities on derivatives were of less importance except for Hungary, where the average valuation adjustment amounted to $5.1 \%$ of GDP (close to the VE on assets) - which is again a reflection of the important role of SPEs in Hungary.

Figure 3. Decomposition of the valuation effect on foreign liabilities of CEE economies for the years 2005-2013 (by investment type)
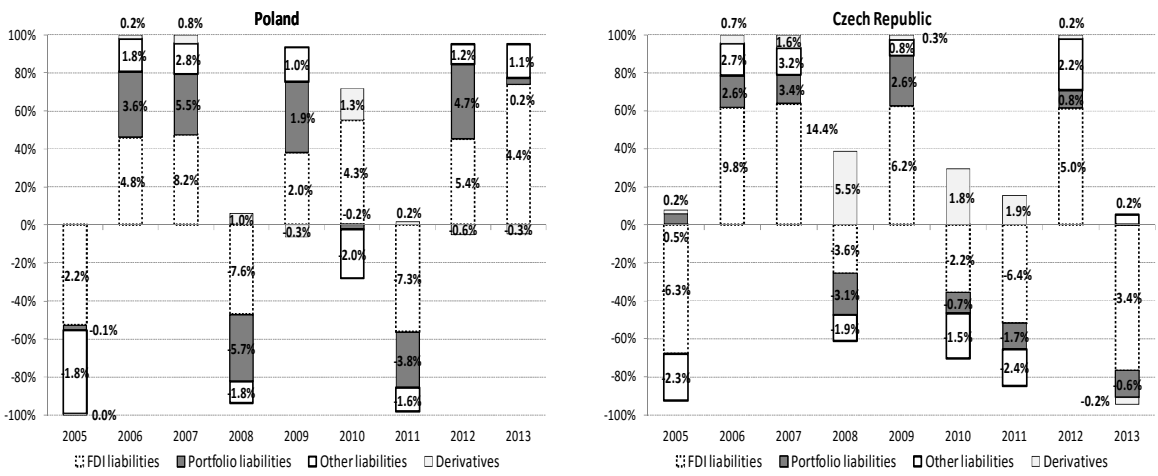

${ }^{9}$ See comment in the previous footnote.

${ }^{10}$ The size of the valuation effect may depend to a large extent on the method of valuation applied to a given type of foreign investment. Damgaard and Elkjaer (2014) and Kumah et al. (2009) indicate that the valuation method and the estimation technique can significantly affect a country's international investment position. Damgaard and Elkjaer (2014) exemplify this using the IIP data on FDIs for Denmark. Danish unlisted FDI equity liabilities vary from $22 \%$ to $156 \%$ of GDP depending on the estimation technique being applied under the price to earnings valuation method. To make cross-national comparisons easier the IMF implemented the Balance of Payments and International Investment Position Manual, sixth edition (IMF, 2009). However, as Damgaard and Elkjaer (2014) point out, the manual recommends seven methods for valuing unlisted FDI which makes international comparisons difficult. 
Figure 3 continued
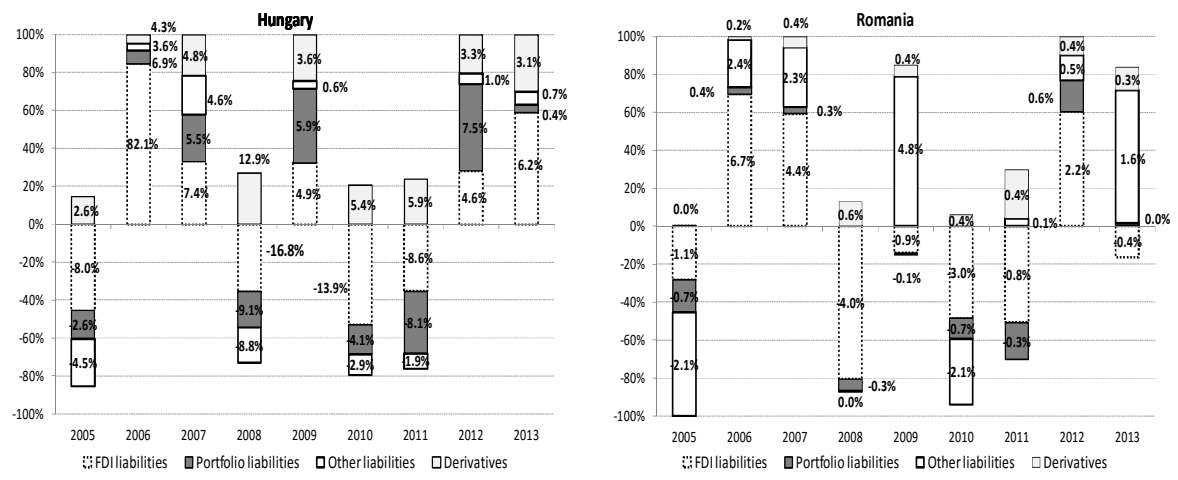

Other remarks: The height of the bar for each year is equal to $100 \%$ and is measured on the $y$-axis. The height of a section of the bar represents the share of a given type of liability in the total VE in a given year. Numbers provided within a bar or alongside represent valuation effects for the respective liabilities presented as a share of GDP in a given year.

Source: as in Figure 1.

It worth mentioning that the sign relating to the VE (both on assets and liabilities) was frequently changing from year to year. The pattern of the sign changes was similar across countries, which proves that the VE depends to a large extent on the general price fluctuations in financial markets which are positively correlated across countries (and not just on the country specific structure of the IIP).

One should bear in mind that the relative significance of valuation adjustments for a given type of investment (expressed as a percentage of GDP) is an outcome of the valuation variability and the size of the investment stock. In order to isolate the influence of the size of investment stock and look specifically at price fluctuations, one can measure valuation adjustments in relation to prevailing stocks of these investments. Using this approach, it is quite apparent that in all CEE countries derivatives (not surprisingly) experienced the largest price fluctuations, followed by FDIs and portfolio investments. For these two latter types of investments, equity instruments were the major reason for valuation adjustments.

\section{Conclusions}

During the last decade CEE economies experienced a change in foreign assets and liabilities that contributed to a significant decrease in the net IIP. 
The path of these changes was not smooth because the underlying factors were affecting the net IIP in opposite directions and in a variable manner. One of these factors was the valuation adjustment to existing stocks of assets and liabilities.

The valuation effect was the key determinant of the net IIP changes in the short run (i.e. for most observed years). Nevertheless, in the long-run (i.e. from the perspective of the whole analysed period) its influence decreases as valuation gains and losses tend to cancel each other out, whereas surpluses of financial flows tend to persist. Because the VE is relatively volatile (the sign relating to its influence frequently changes from positive to negative and vice versa), when evaluating the IIP it is important to analyse its dynamics over the mid and long-term.

The significance of the valuation effect for determining the net IIP turned out not to be investment-type specific because valuations of both the short-term and long-term investments contributed in a large part to the change in the net IIP. At the same time, the importance of the VE by investment type was differentiated across countries and time as well as between assets and liabilities. Although no specific type of international investment was dominant in creating exposure to the VE consistently, the prices of derivatives, followed by FDIs and portfolio investments, were the most volatile in percentage terms. For the latter two types of investments, the equity component was the major contributor to price fluctuations.

There are similarities in the dynamics of the VE in CEE countries, which proves that the VE depends to a large extent on the general price fluctuations in financial markets that nowadays exhibit strong positive correlations across countries (not just on the country specific structure of the IIP). Undoubtedly, the significance of the valuation effect in the analysed period was positively affected by sudden fluctuations in the prices of financial instruments amid the world financial crisis starting in 2008.

\section{References}

Damgaard, J., \& Elkjaer, T. (2014). Foreign Direct Investment and the External Wealth of Nations: How Important is Valuation? Review of Income and Wealth, 60(2). http://dx.doi.org/10.1111/roiw.12098.

Devereux, M. B., \& Sutherland, A. (2010). Valuation effects and the dynamics of net external assets. Journal of International Economics, 80(1). http://dx.doi.org/10.1016/j.jinteco.2009.06.001.

ECB (2007). European Union Balance of Payments/International Investment Position. Statistical methods. Frankfurt: European Central Bank. 


\section{Konrad Sobański}

Gourinchas, P.-O. (2008). Valuation Effects and External Adjustment: A Review. In K. Cowan, S. Edwards, \& R. O. Valdes, Current Account and External Financing, 12.

Gourinchas, P.-O., \& Rey, H. (2013). External Adjustment, Global Imbalances and Valuation Effects. NBER Working Papers (19240).

Higgins, M., Klitgaard, T., \& Tille, C. (2007). Borrowing Without Debt? Understanding the U.S. International Investment Position. Business Economics, 42(1). http://dx.doi.org/10.2145/20070102.

IMF (2009). Balance of Payments and International Investment Position Manual (6th ed.). Washington, D.C.: International Monetary Fund.

Kumah, E., Damgaard, J., \& Elkjaer, T. (2009). Valuation of Unlisted Direct Investment Equity. IMF Working Paper (09/242).

Lane, P. R., \& Milesi-Ferretti, G. M. (2001). The external wealth of nations: measures of foreign assets and liabilities for industrial and developing countries. Journal of International Economics, 55(2). http://dx.doi.org/10.1016/ S0022-1996(01)00102-7.

Lane, P. R., \& Milesi-Ferretti, G. M. (2007a). A Global Perspective on External Positions. In R. H. Clarida (Ed.), G7 Current Account Imbalances. Sustainability and Adjustment. Chicago and London: University of Chicago Press Books.

Lane, P. R., \& Milesi-Ferretti, G. M. (2007b). Europe and global imbalances. Economic Policy, 22(51). http://dx.doi.org/10.1111/j.1468-0327.2007.00184.x.

Macías, A. \& Nash, A. (2007). Efectos de valoración en la posición de inversión internacional de España (Valuation effects in the Spanish International Investment Position), Documentos Ocasionales No. 0704, Banco de Espana.

MNB (2014a). Methodological notes on the statistical treatment of special purpose entities (SPEs), Magyar Nemzeti Bank, Retrieved from http://english.mnb.hu/ Root/Dokumentumtar/ENMNB/Statisztika/mnben_modszertanok/fmmodszerta n_scv_en.pdf (14.06.2014).

MNB (2014b). Report on the Balance of Payments, Magyar Nemzeti Bank, April, Retrieved from http://english.mnb.hu/Root/Dokumentumtar/ENMNB/Kiadvan yok/report-on-the-balance-of-payments/2014/Report_on_the_Balance_of_Pay ments.pdf (14.06.2014).

Sobański, K. (2010). Tendencje w bilansie płatniczym i międzynarodowej pozycji inwestycyjnej krajów Europy Środkowo-Wschodniej w latach 1998-2007. In E. Najlepszy, K. Sobański. Niestabilność równowagi zewnętrznej krajów rozwijających się. Warszawa: Polskie Wydawnictwo Ekonomiczne.

UN Economic Commission for Europe, Eurostat, OECD (2011). The Impact of Globalization on National Accounts. New York \& Geneva: United Nations. 


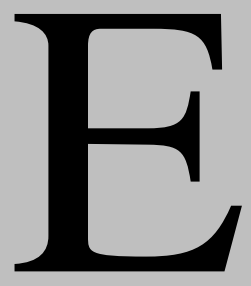

Q U I L I B R I U M

Quarterly Journal of Economics and Economic Policy

\section{Lobur Markets}


